\title{
2. STRUCTURE AND TECTONICS OF THE MARIANA ARC AND FORE-ARC: DRILLSITE SELECTION SURVEYS ${ }^{1}$
}

\author{
nald M. Hussong and Patricia Fryer, Hawaii Institute of Geophysics, University of Hawaii, Honolulu, Hawaii
}

\begin{abstract}
Site selection surveys conducted in preparation for drilling on the Mariana arc, fore-arc, and trench provide a complete background of geologic and geophysical information about the region. The Pacific Ocean basin crust east of the trench is of probable late Jurassic age. No sediments have accumulated in the trench axis or on the inner wall of the trench, but on the fore-arc sediments thicken to over 3 seconds toward the volcanic arc. Paradoxically, the arc-trench region is one of convergence of two large oceanic plates, yet tensional faulting pervades the area. Large seamounts on the outer fore-arc, near the trench, have some characteristics of submarine volcanoes but are located far from regions of magma genesis beneath the present volcanic arc.
\end{abstract}

\section{INTRODUCTION}

The easternmost portion of the DSDP Legs 59 and 60 drilling transect across the Philippine Sea along $18^{\circ} \mathrm{N}$ latitude was planned in order to study the structure, composition, and geologic history of a trench and volcanic arc formed by the convergence of two oceanic lithospheric plates. This chapter will describe the results of two geological and geophysical research cruises to the region (Fig. 1) that were conducted by the Hawaii Institute of Geophysics to provide data for drill site selection. These data sets, a regional reconnaissance effort in 1976 (Fig. 2) followed by a more detailed survey in 1977 (Fig. 3), were augmented by multichannel seismic reflection profiles collected in 1977 by the Lamont-Doherty Geological Observatory (Mrozowski et al., this volume) and by some data from the Scripps Institution of Oceanography. The drilling targets were chosen along a transect across the central portion of the crescent-shaped arc at $18^{\circ} \mathrm{N}$ (Fig. 1). The fore-arc region between the trench axis and the volcanic arc is nearly $200 \mathrm{~km}$ wide and on a regional scale is covered by a gently dipping volcanogenic apron of sediments to within about $40 \mathrm{~km}$ of the trench. The southern Mariana islands of Guam and Saipan are composed of uplifted arc rocks and calcareous sediments with ages from Recent to Eocene (Tracey et al., 1964). They are located along an arcuate trend that can be projected to the fore-arc region at $18^{\circ} \mathrm{N}$. Considering their ages as evidence for the age of the fore-arc itself, Karig $(1971,1972)$ suggested that it is partly composed of the eastern remnants of the Palau-Kyushu Ridge (rifted in the Paleogene by the initiation of spreading in the Parece Vela Basin) and the West Mariana Ridge (rifted late in the Neogene by the initiation of spreading in the Mariana Trough). Within $30-40 \mathrm{~km}$ west of the trench axis at $18^{\circ} \mathrm{N}$, a break in slope of the fore-arc occurs. From a depth of about $\mathbf{4 0 0 0}$ meters to the trench axis at 8000 meters, the inner wall of the trench dips more steeply. Karig and Sharman (1975)

\footnotetext{
${ }^{1}$ Initial Reports of the Deep Sea Drilling Project, Volume 60.
}

considered material from the trench axis up to and including this trench slope break in the mass of oceanic plate sediments that they suggest are offscraped and uplifted by imbricate thrusting to form an accreting prism on the leading edge of the overriding plate. Thus the apparent north-south elongated seamounts that occur at some latitudes along the trench-slope break, and rise thousands of meters above the regional depth, would be included in the accretionary prism.

Based on this information and the structural models available in 1975, three drilling targets were proposed:

1) SP 1, on the Pacific plate, to serve as a reference site to characterize the nature of the sediments and upper crustal rocks being carried into the subduction zone;

2) SP 2, on the inner trench wall, to sample the accreting prism of sediments offscraped from the subducted plate and added to the overriding plate; and

3) SP 3, on the arc massif just east of the volcanic axis to sample the arc sediments and basement rocks.

A more detailed description of drilling objectives, including a brief history of the refining of the objectives based on the results of the site selection surveys, can be found in Hussong and Uyeda, "Mariana Arc and ForeArc, Background and Objectives," this volume.

\section{PRINCIPAL SITE SURVEY RESULTS}

All conventional geophysical profiling data were acquired during the HIG cruises, including bathymetry, gravity, magnetics, and single-channel seismic reflections (digitally recorded during some key profiles). In addition, ocean bottom seismometer and sonobuoy refraction seismic data and a few piston core and dredge samples were collected. All ship's navigation for these surveys was satellite-controlled, with positions between fixes interpolated and adjusted using continuously recorded gyro-controlled ship's heading and speedthrough-water obtained from a through-hull electromagnetic sensor.

\section{Bathymetry}

A bathymetric map of the entire area based on $3.5-\mathrm{kHz}$ reflection data from both the HIG cruises and 


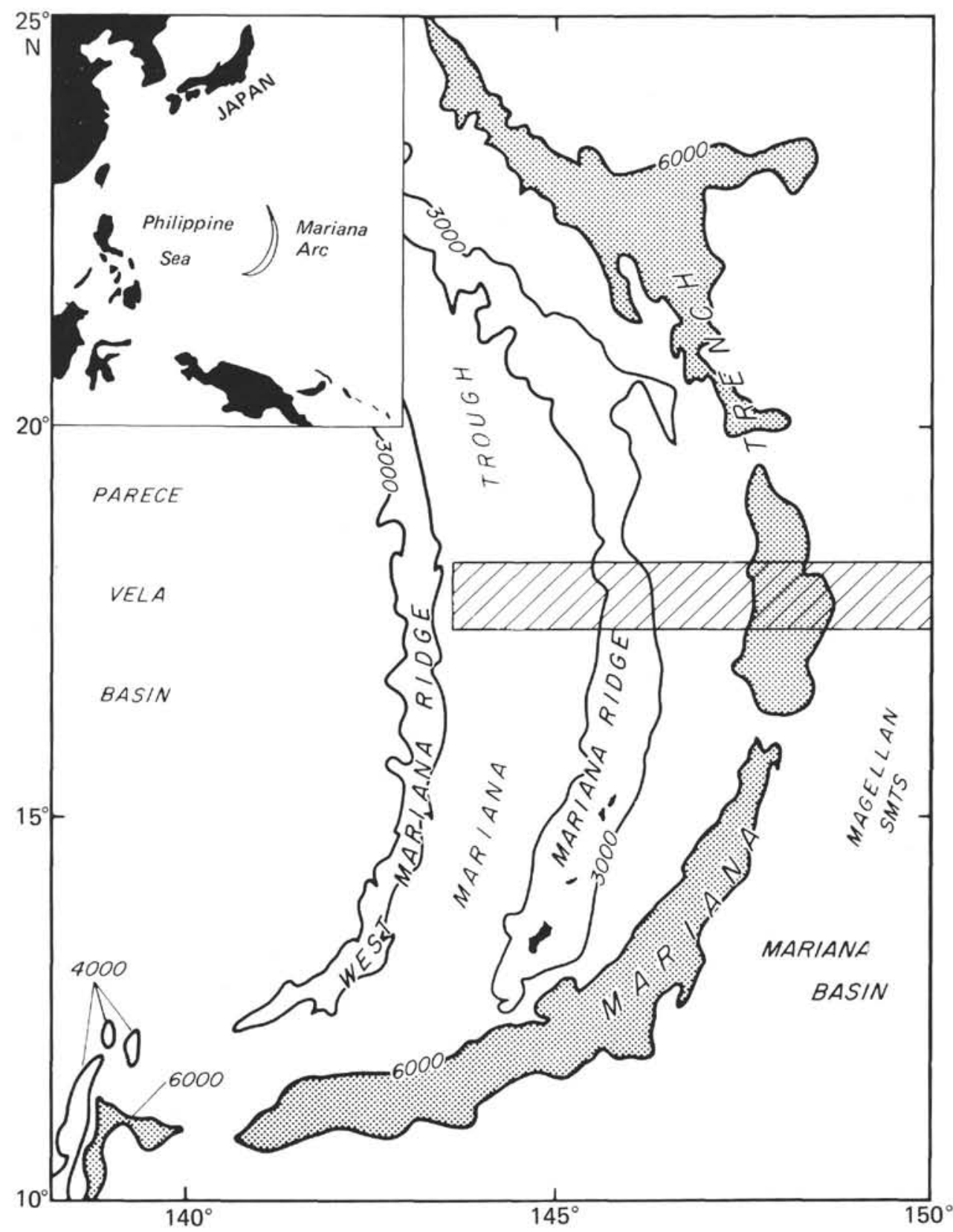

Figure 1. Location map of major features of the Philippine Sea and the Mariana Island arc. Region in box is described in the text.

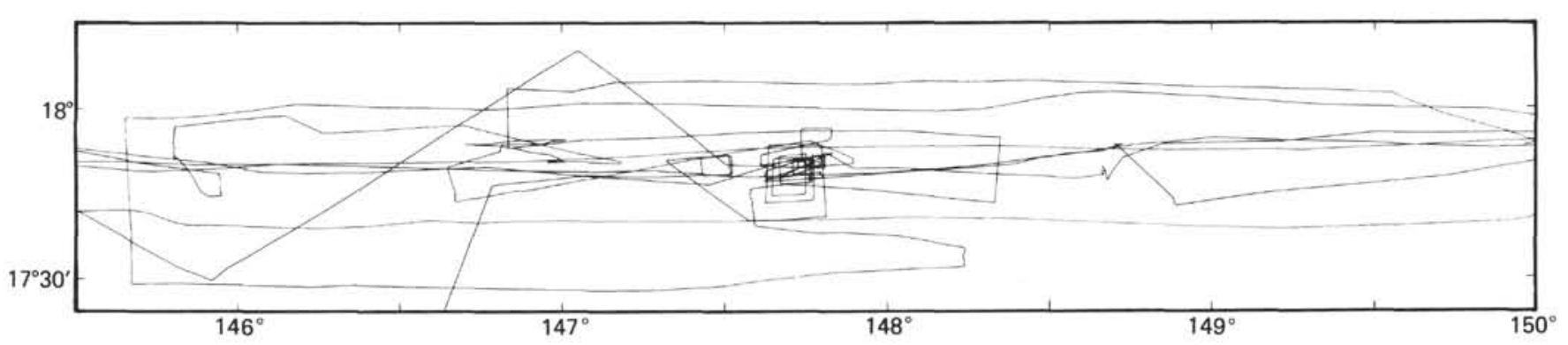

Figure 2. Ship tracks of 1976 survey by the Hawaii Institute of Geophysics. 




Figure 3. Ship tracks of 1977 survey by the Hawaii Institute of Geophysics.

the L-DGO and SIO lines is presented by Hussong (this volume) on Plate 1 in the back of the volume. A portion of this map is reproduced in Figure 4, with selected tracklines, the Leg 60 drill sites, and major seamounts (shaded areas) included on the bathymetry.

Seamounts of the Magellan group lie on the Pacific plate east of the Mariana Trench. The shaded region 1 in Figure 4 is one of these seamounts that has been carried into the trench axis. It rises about 2500 meters above the surrounding seafloor. A single-channel reflection seismic profile (Fig. 5), although inadequate for resolving any sub-bottom structural detail, shows the position of Seamount No. 1 relative to the trench axis. Although the trench axis depth rises 1300 meters $(>1.7 \mathrm{~s})$ because of the impinging seamount, there does not seem to be much deformation of the adjacent base of the inner trench wall.

The Pacific basin seafloor with no seamounts is broken by apparent normal faults as the top of the ocean crust is stretched where the lithospheric plate bends prior to subduction. The resultant horst and graben morphology starts about $70 \mathrm{~km}$ east of the trench axis (Fig. 6) and increases to the west, becoming fault throws of $300-400$ meters near the axis. The faults can be traced between profiles, with a strike that is subparallel to the trench (Fig. 7).

The western wall of the trench rises at angles of as much as $9^{\circ}$ from axial depths of over 8400 meters to 4000-4500 meters at the trench slope break (near $147^{\circ} 30^{\prime} \mathrm{E}$ in Fig. 4). The inner trench wall is deeply incised near $17^{\circ} 45^{\prime} \mathrm{N}$ by what might be a slump (a hummocky base to the re-entrant observed at about 7100 meters was the location of Site 461) or a canyon that trends from the south at depths of 4600-6800 meters. The trench axis is displaced to the east adjacent to the re-entrant in the trench wall.

At $18^{\circ} \mathrm{N}$ a seamount (No. 2 on Fig. 4) rises 1000 meters above the regional depth on the trench slope break. It is only $30 \mathrm{~km}$ from the trench axis (Fig. 5), so is probably less than $15 \mathrm{~km}$ above the subducting oceanic plate. Although the shape of the seamount might suggest that it is volcanic (Fig. 8), its position relative to any magma source makes such an origin unlikely. Alternatively, Seamount No. 2 may be oceanic or arc material uplifted by tectonic activity related to the plate convergence and/or the subduction of ocean basin seamounts.
Farther west, Seamount No. 3 (Fig. 4) rises over 2000 meters above the surrounding seafloor (Fig. 9). It is about $60 \mathrm{~km}$ from the trench axis, over $140 \mathrm{~km}$ east of the presently active volcanic islands, and probably about $20 \mathrm{~km}$ above the top of the subducing slab. Again, although the shape of Seamount No. 3 is more like a volcanic pile than an upthrust block, considering the configuration of the arc and the Benioff Zone, it seems too distant from any likely magma source.

The gently dipping fore-arc sediment apron is also broken by high-angle faulting that becomes more intense closer to the trench. These faults are noted by Hussong (this volume) and shown on Plate 2 in the back of this volume (by Mrozowski et al., this volume) and by Mrozowski and Hayes (1980). A migrated multichannel seismic reflection profile (Fig. 10) collected by Mrozowski and Hayes (1980) from the fore-arc, about $10 \mathrm{~km}$ west of Site 459 , is a particularly dramatic exhibit of these fore-arc faults.

If individual volcanic seamounts and islands are not counted, on a regional basis the shallowest portion of the Mariana Arc is about $30 \mathrm{~km}$ east of the present axis of volcanism near $18^{\circ} \mathrm{N}$. This is about the position where the Guam-Rota-Tinian-Saipan trend would be at $18^{\circ} \mathrm{N}$ latitude. Regional depths at this position are about 2500 meters, whereas the regional depth of the saddle areas between the presently active volcanic islands is about 2700 meters. It appears, therefore, that the present axis of arc volcanism is offset about $25 \mathrm{~km}$ to the back-arc side of the most shallow, central part of the arc massif.

The $18^{\circ} \mathrm{N}$ transect area includes the active volcanic islands of Alamagan and Pagan. The distance between these volcanoes is $60 \mathrm{~km}$, which is approximately the average spacing of the volcanic islands along the northern and central Mariana arc.

\section{Sediment Distribution}

On the oceanic plate east of the trench a thin $(40-\mathrm{m})$ layer of surface sediment overlies roughly 200 meters of partially lithified sediments (velocities $<2 \mathrm{~km} / \mathrm{s}$ ). The 40 -meter reflector is most easily traced on $3.5-\mathrm{kHz}$ reflection records, whereas the deep $(\sim 200-\mathrm{m})$ interface is intermittently detected on airgun profile records such as the eastern end of Figure 6 and the reflection profile on Plate 2 (back pocket). Beneath these layers 400 to 600 meters of consolidated sediment (velocities $3-3.5 \mathrm{~km} / \mathrm{s}$ ) 


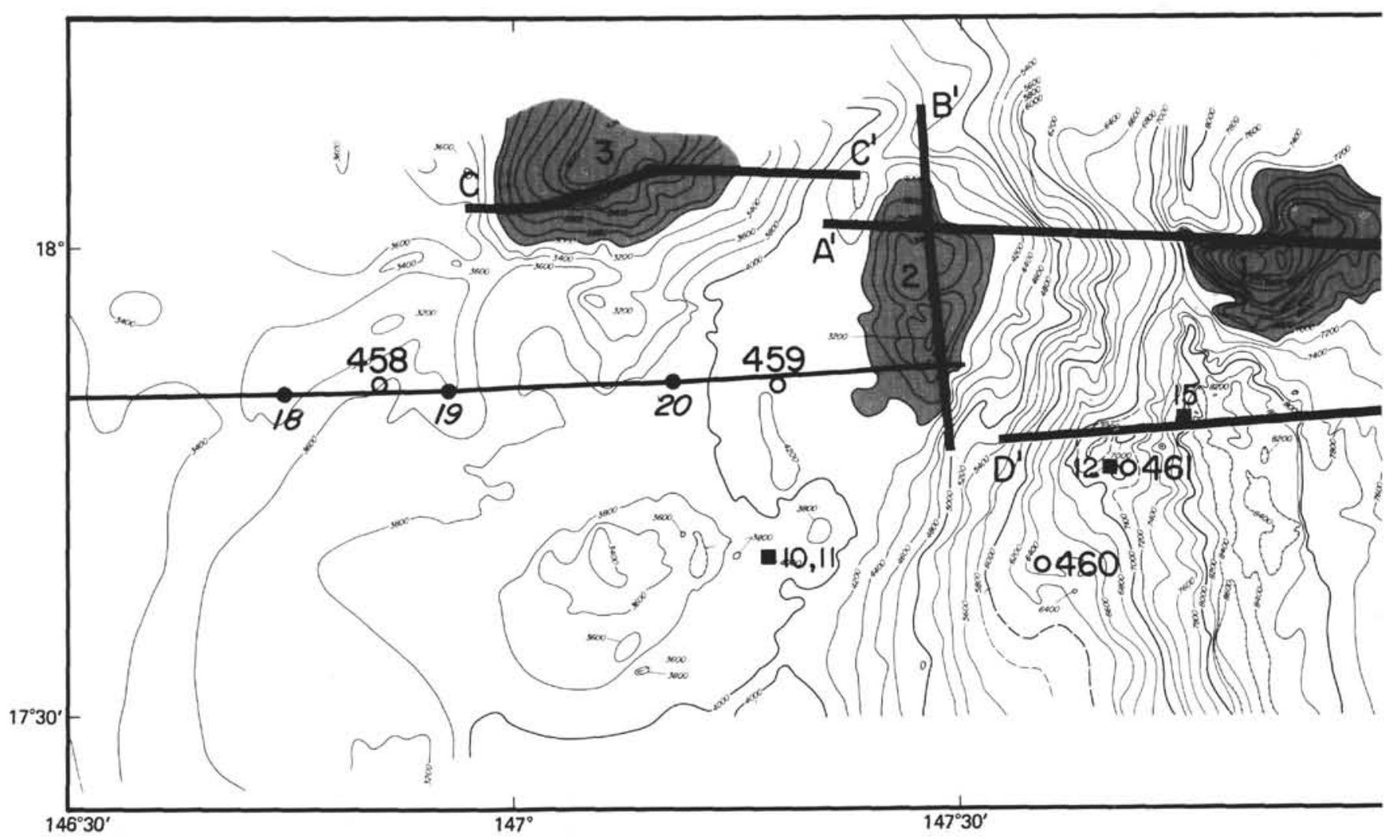

Figure 4. Bathymetry map of the Mariana fore-arc and trench. (Depth in corrected meters; open circles are drill sites from DSDP Leg 60; closed circles connected with lines are the seismic refraction sonobuoy profiles of LaTraille and Hussong, 1980; solid squares are HIG core stations; reflection profiles are located for other figures in the chapter; shaded areas 1, 2, and 3 are seamounts discussed in text.)

overlie material considered to be crystalline rock (velocities $>4 \mathrm{~km} / \mathrm{s}$ ), as detected by sonobuoy measurements (LaTraille and Hussong, 1980).

The trench axis and the inner wall of the trench are virtually devoid of sediments that can be detected seismically. Reflection records reveal no material ponded in the trench, although a free fall core collected from the axis contains material that may be part of the slump deposit (see core descriptions, Table 1). We observed no sediment draped over the face of the inner trench wall. The inner wall of the trench has a few re-entrants, or shelves, which in some cases have shallow accumulations of flat-lying sediment. The thickest sediment was 200 meters in a pond at a depth of 7200 meters at $17^{\circ}$ $47.5^{\prime} \mathrm{N} 147^{\circ} 39.0^{\prime} \mathrm{E}$. Unfortunately, this pond is too deep to drill effectively with the Glomar Challenger. Two other sites may have some sediment, although actual ponds are poorly identified. These are at $17^{\circ} 39.5^{\prime} \mathrm{N}$ and $147^{\circ} 35.0^{\prime} \mathrm{E}(6460 \mathrm{~m})$, where one profile suggests a small pond (see Fig. 3 in the Site 460 chapter, this volume), and at $17^{\circ} 52.5^{\prime} \mathrm{N}$ and $147^{\circ} 38.0^{\prime} \mathrm{E}(6300 \mathrm{~m})$, where a short section with flat bottom on the reflection profile looks like it may be sediment-filled. No actual thickness of sediment was observed on this profile.

The top of the inner trench wall lacks observable acoustic layering. The absence of sediment reflections may be attributable to tectonic disturbance in the region rather than to an outcropping of acoustic basement.
Sonobuoy, OBS, and multichannel seismic velocity determinations near the trench-slope break all indicate a substantial thickness of low-velocity material (about 1 $\mathrm{km}$ thick with velocity $3 \mathrm{~km} / \mathrm{s}$ ). West of the trench-slope break discrete sediment layers occur and appear to thicken westward over a gradually better-defined and deepening acoustic basement. Except for the high-angle faults, which become less frequent and less pronounced toward the volcanic arc (see Mrozowski and Hayes, 1980), the fore-arc sediment are undisturbed. No folding or other evidence of compression is observed, and there are few pronounced unconformities in the thick sediment section.

\section{Magnetics}

A total magnetic intensity map is presented on Plate 1 (back pocket and Hussong, this volume). On the Pacific oceanic plate a series of linear magnetic anomalies, striking about $35^{\circ}-45^{\circ}$ true, are easily identified. The trend, amplitude, and wavelength of these anomalies are similar to the Japanese lineations described by Hilde et al. (1976). It is likely therefore that these anomalies in the vicinity of the Magellan Seamounts in northern Mariana Basin are also products of Mesozoic seafloor spreading from the Kula-Pacific Ridge. Preliminary modeling of the anomalies, as part of the drill site selection effort, tentatively identify them as Anomalies M-23 through $\mathrm{M}-25$. If these identifications are correct, Site 


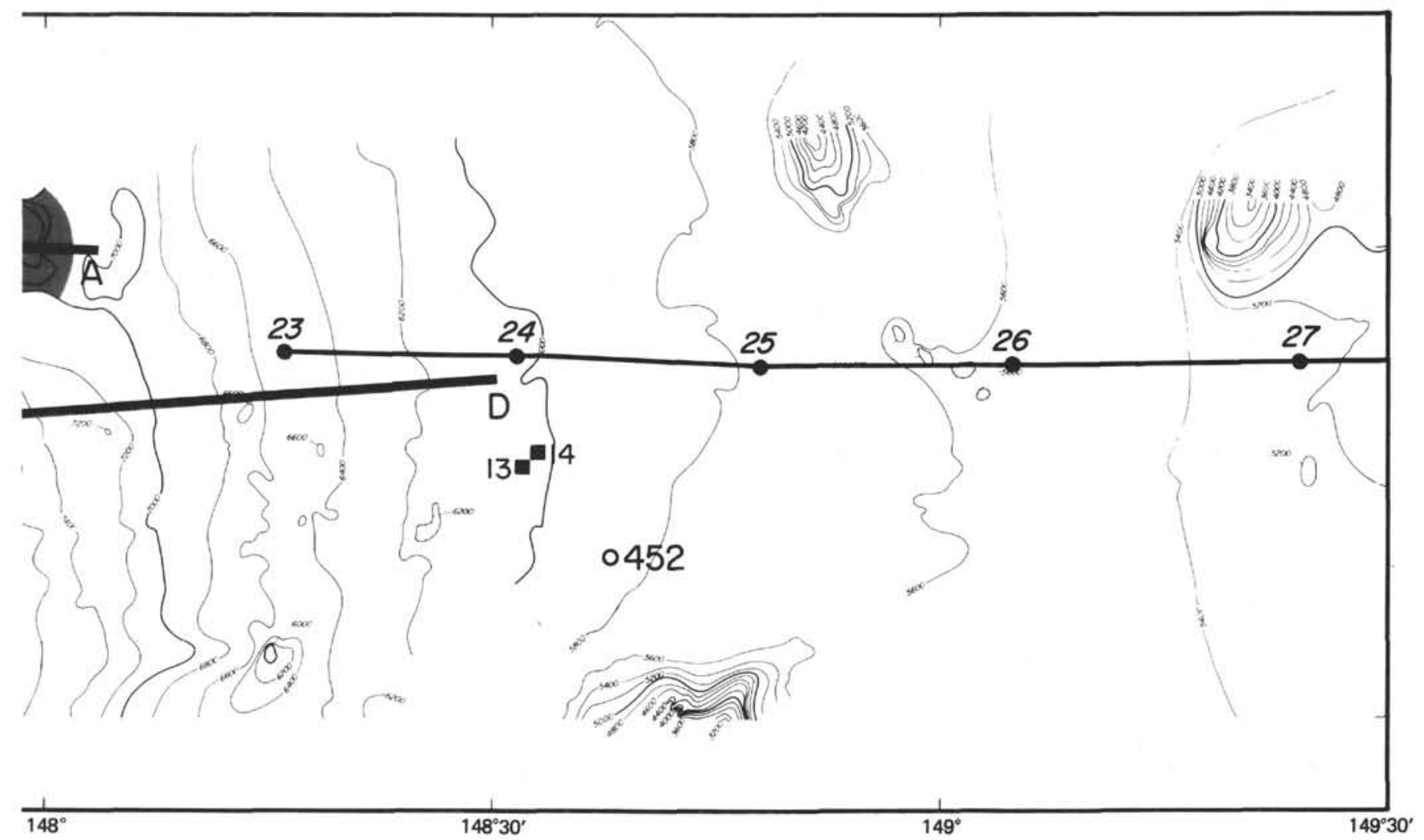

Figure 4. (Continued).

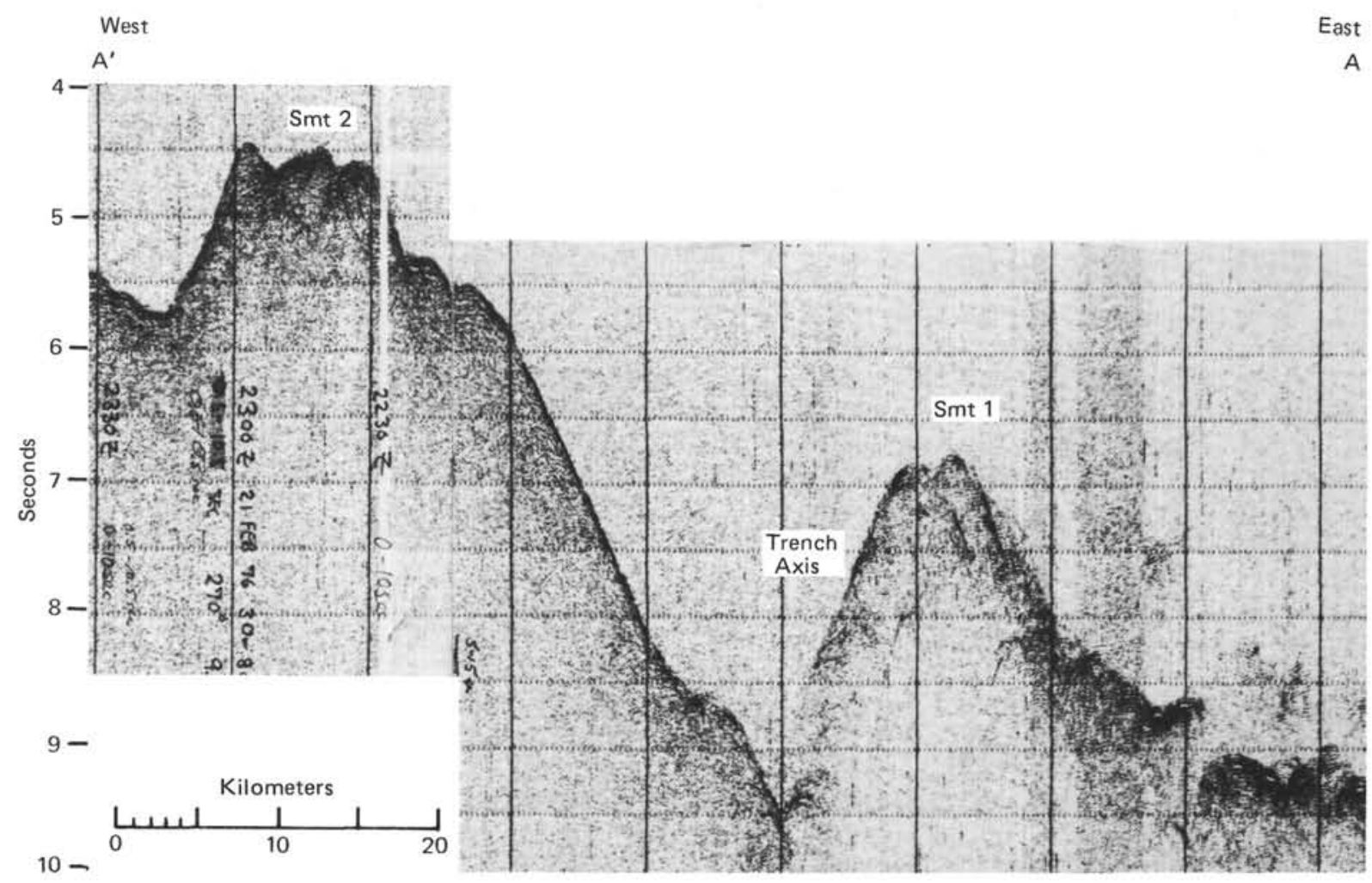

Figure 5. Single-channel airgun profile across Seamount No. 1, the Mariana Trench axis, and Seamount No. 2. (Data filtered 30-80 Hz.) 


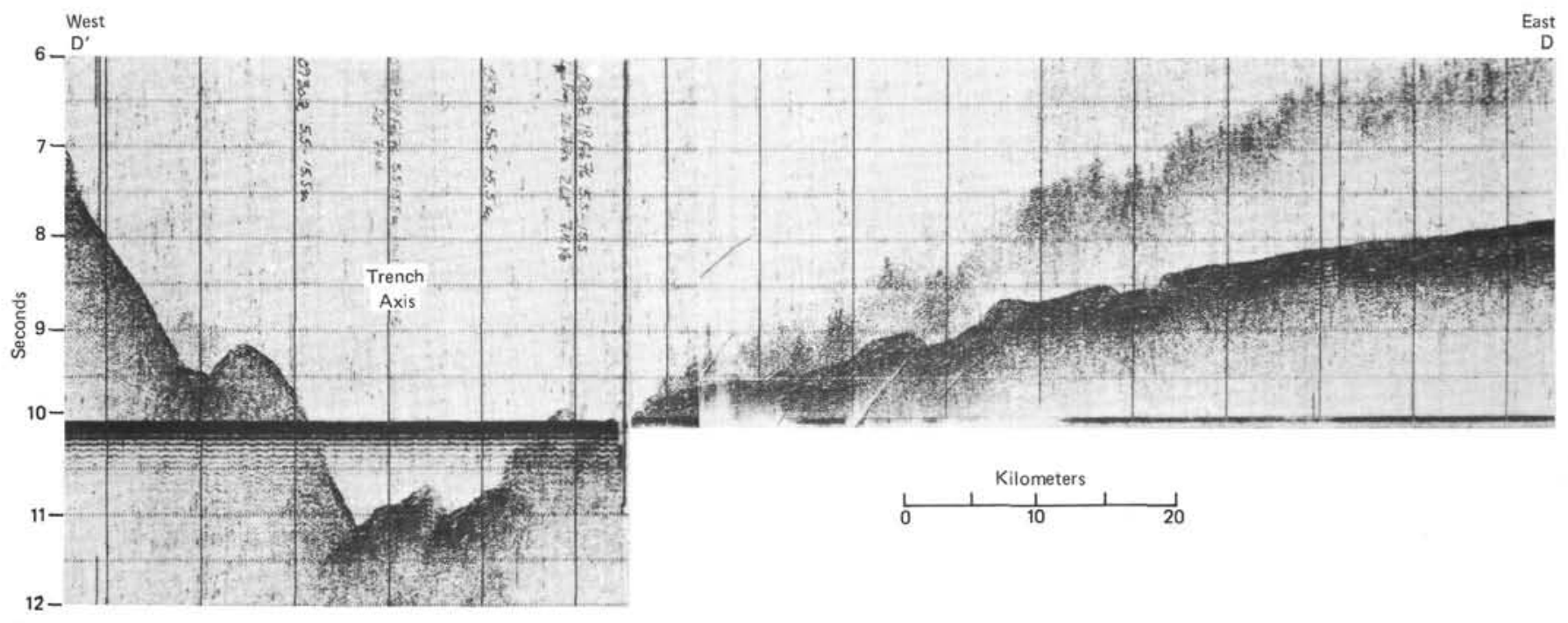

Figure 6. Single-channel airgun reflection seismic profile, showing development of tensional faulting on the upper surface of the Pacific oceanic lithospheric plate as it bends into the subduction zone.

452 was drilled on Late Jurassic ocean crust that formed $150 \mathrm{Ma}$ according to the time scale of Larson and Hilde (1975).

The portion of the total intensity magnetic field map that covers the fore-arc region west of the trench axis (Fig. 11) shows many strong dipoles associated with the seamounts in this area. The position of the seamounts described in the Bathymetry section of this chapter are numbered and indicated by shaded regions on the magnetic field. Note that Seamount No. 1, the apparent oceanic plate volcano partially in the axis of the trench, and Seamount No. 3, on the fore-arc, are associated with strong magnetic anomalies. The seamount on the trench slope break (No. 2), however, has a very small magnetic expression.

\section{Gravity}

As with the other geophysical parameters, a free air gravity (FAA) anomaly map of the entire Leg 60 survey area is described by Hussong (this, volume) and illustrated on Plate 1 (back pocket). A typical profile of FAA and bathymetry running east-west along $17^{\circ} 50^{\prime} \mathrm{N}$ is shown as Figure 12. In general, as expected, the FAA profile mimics the bathymetry. An outer gravity high, although somewhat confused by the occurrence of seamounts on the Pacific basin floor, occurs above the oceanic lithospheric plate where it begins to bend in response to subduction forces. The FAA expression of the trench axis and the trench slope break coincide with the bathymetric expression of these features.

On the fore-arc, however, a large ( $>40$-mgal) gravity anomaly $100 \mathrm{~km}$ west of the trench axis has little bathymetric expression. In plan view (Fig. 13) the amplitude and short wavelength of this gravity anomaly, centered at $17^{\circ} 54^{\prime} \mathrm{N}$ and $146^{\circ} 51^{\prime} \mathrm{E}$, is striking because it is almost as large as nearby anomalies over large seamounts. A model that would satisfy the gravity data requires a cone of material with an excess density of over $0.3 \mathrm{~g} /$ $\mathrm{cm}^{3}$, with a base less than $10 \mathrm{~km}$ in diameter, and a slope of $15^{\circ}$ rising to the seafloor from a sub-bottom depth of about $2 \mathrm{~km}$. This model is designed to imitate a buried volcano. The gravity anomaly can of course be modeled in a great variety of shapes, depths, and density contrasts. Regardless, to produce the observed 40mgal, short-wavelength anomaly, the causative body is probably shallow, of limited lateral extent, and of high density contrast. A sonobuoy refraction profile conducted as part of the site survey (LaTraille and Hussong, 1980) passed over the southern flank of the gravity profile and showed a slight $(1-\mathrm{km})$ rise in the deep crustal layer $(6.2 \mathrm{~km} / \mathrm{s})$. Site 458 was subsequently drilled on this gravity anomaly, partly as an attempt to sample material that might be providing the necessary excess mass.

Figure 13 also has shaded areas that show the positions of the three seamounts discussed in the Bathymetry and Magnetics portions of this chapter. Seamounts Nos. 1 and 3 have strong associated gravity anomalies, whereas Seamount No. 3 on the trench-slope break has a small gravity anomaly. Seamount No. 1 is probably a midplate submarine volcano, and Seamount No. 3, with proportionally large magnetic and gravity anomalies, may also be volcanic. Seamount No. 2, with quite subdued anomalies, is probably not a volcano but a serpentine diapir, obducted oceanic plate material, or other arc rock and sediment that was uplifted in response to tectonic phenomena related to plate convergence.

\section{Refraction Seismology}

A line of sonobuoy refraction stations, using explosive charges for sound sources, was run across the survey area in 1976 and has been reported by LaTraille and Hussong (1980). The results of this work are summarized in Table 1. These data indicate that this Jurassic portion of the Pacific crust has a velocity structure that is similar to much younger ocean crust, except that Layers 2 and 3 are somewhat thinner than Pacific-wide averages and Layer $2 \mathrm{~A}$ is thicker. The greater thickness 


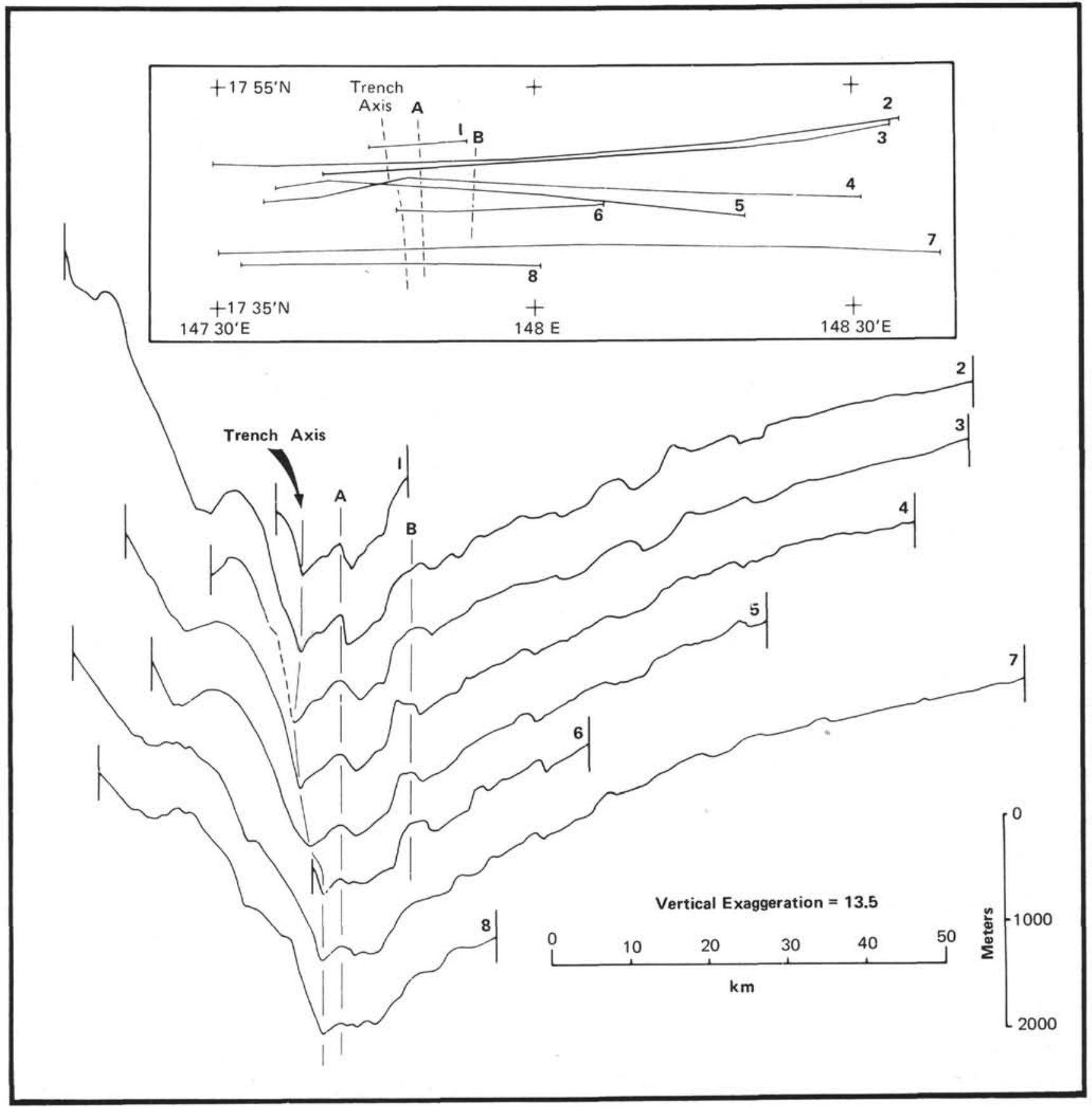

Figure 7. Bathymetric profiles across the Mariana Trench, showing the lateral continuity of the normal faults developed on the subducting plate (see Fig. 6). (From Jones et al., 1978.)

of Layer 2A may be attributable to the midplate volcanism that presumably formed the Magellan Seamounts or to the formation of cherts and limestone in the deep, very old sedimentary sections that produce seismic velocities high enough to be considered Layer $2 \mathrm{~A}$.

LaTraille and Hussong (1980) detected less than one kilometer of unconsolidated sediments on the outer 100 $\mathrm{km}$ of the fore-arc. The sediments are underlain by a layer with high relief and velocities that vary from $3.0-5.8 \mathrm{~km} / \mathrm{s}$; they may be buried arc volcanics. At a sub-bottom depth of 4-5 $\mathrm{km}$ the crustal velocities uniformly approach $6.1-6.5 \mathrm{~km} / \mathrm{s}$. This higher-velocity material may be the top of the old ocean basin or backarc basin crust that underlies the Marianas (LaTraille and Hussong, 1980).

Several ocean bottom seismic stations were made on the fore-arc in 1977; data analysis is incomplete.

\section{Sediment Cores and Rock Dredges}

A total of six cores were taken near the proposed DSDP sites. Locations are given in Figure 4. The results of piston core drilling are given in Table 2 . Two cores from the old ocean crust east of the Mariana Trench contain pelagic clay. One core obtained near the trench- 


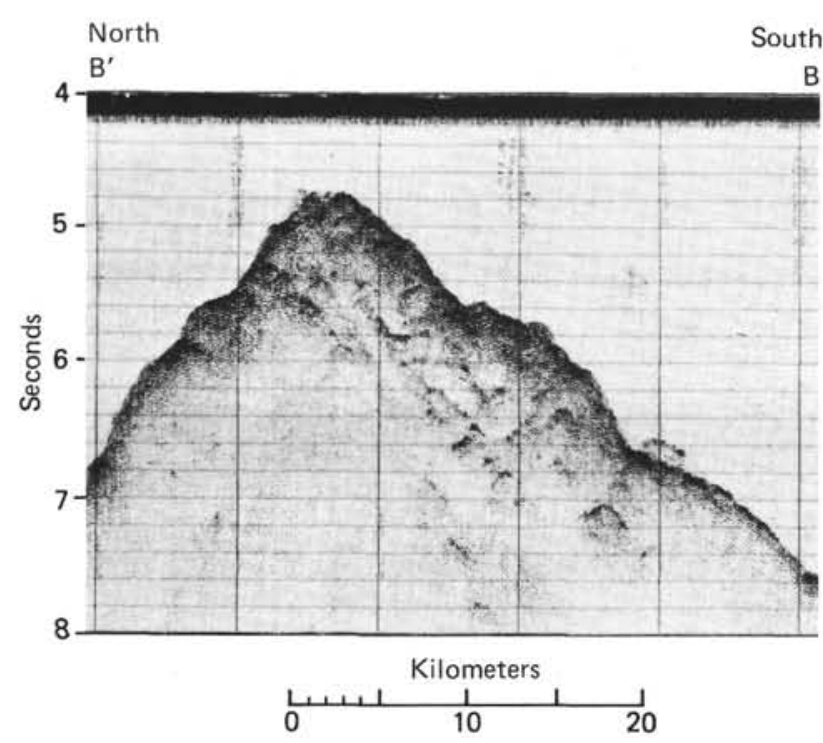

Figure 8. North-south single-channel airgun reflection seismic profile across Seamount No. 2 on the trench-slope break.

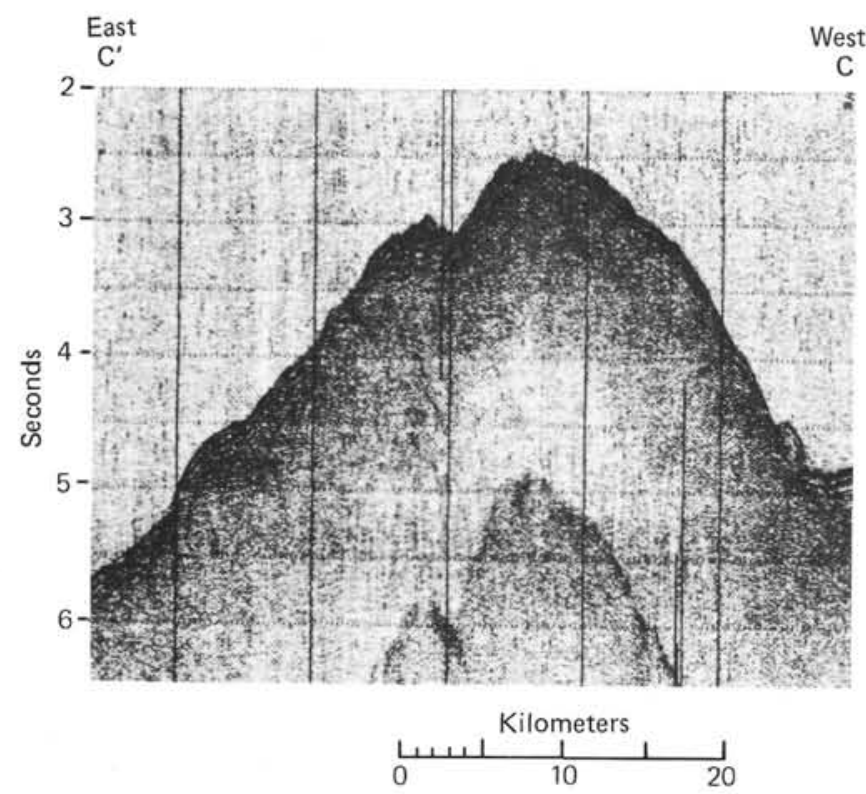

Figure 9. Single-channel airgun reflection seismic profile across Seamount No. 3.

slope break contained clayey silt composed primarily of volcanic ash with some Pleistocene to Holocene foraminifers. Two cores from midway between the arc and the trench contained clayey silt composed of volcanic ash and some radiolarians interbedded with layers of pumice. One core taken in the trench axis at a depth of 7800 meters contained a mixture of lithic, detrital, and pelagic material; mottled brown and blue gray clays; fragments of serpentine; and patches of partially dissolved calcareous material (foraminiferal tests). This material probably represents a slump deposit, presumably derived from the inner trench wall.

One rock dredge was made in the fore-arc region. It was taken from an outcrop of acoustically chaotic mate- rial in the midslope region where the sediment apron from the active arc begins to thin out. The material recovered was semilithified siltstone composed of pyroclastics, small amounts of radiolarian fragments, and calcareous nannofossils.

\section{CONCLUSIONS; REVISED DRILLING TARGETS}

1. Linear magnetic anomalies probably produced by Late Jurassic seafloor spreading from the Kula-Pacific Spreading Center occur on the Pacific Basin seafloor adjacent to the Mariana Trench near $18^{\circ} \mathrm{N}$.

2. There are no ponded sediments in this portion of the Mariana Trench axis. Almost no sediments are observed on seismic reflection profiles anywhere on the inner wall of the trench below the trench slope break ( 4200-m depth). No accretionary prism of oceanic sediments can be seen on the leading edge of the overriding plate. Although thicknesses vary considerably, on the gently dipping fore-arc west of the trench-slope break the sediment increases toward the volcanic arc. Maximum thickness of these outer fore-arc sediments is about one kilometer. Farther west, within $100 \mathrm{~km}$ of the volcanic arc, sediment thicknesses increase markedly. Acoustic basement exceeds $3 \mathrm{~s}$ in places.

3. No folding, obvious thrusting, or other signs of compression can be seen anywhere on the oceanic plate or on the Mariana arc. High-angle faults, interpreted as normal faults, are observed on the fore-arc as well as on the bending oceanic lithosphere. Based on these surveys, the surface of the entire convergence zone seems to be in tension, except for the actual megashear at the plane of contact between the converging plates.

4. Seamounts on the outer edge of the fore-arc region do not fit our ideas of volcanism in island arcs. A true-scale sketch of the Mariana fore-arc (Fig. 14) illustrates the geometry of this problem. Based on its geophysical signature, Seamount No. 3 would seem to be volcanic (like Seamount No. 1). The origin of Seamount No. 2 is less clear. If any of these seamounts are volcanic and autochthonous, they seem far displaced from the regions of probable magma genesis below the volcanic arc. Volcanism normally occurs in regions where the depth to Benioff Zone seismicity is about $100 \mathrm{~km}$. If the seamounts are volcanoes, perhaps they formed at a time when the trench axis was relatively farther east and the Benioff Zone therefore much deeper. Tectonic erosion of the outer fore-arc may be moving the trench axis closer to the volcanoes.

5. Based on these survey results, the drilling objectives (Hussong and Uyeda, "Mariana Arc and ForeArc, Background and Objectives," this volume) relative to tectonic problems and in the arc were as follows:

1) Site 452: to check the age of the ocean crust, which is tentatively dated as Late Jurassic, as well as to provide a reference site for ocean plate material supplied to the subduction zone;

2) Site 457: to sample the present volcanic arc;

3) Site 458 (an alternate site): to study the nature of the fore-arc and particularly to try to sample material related to the large and unexplained positive gravity anomaly; 


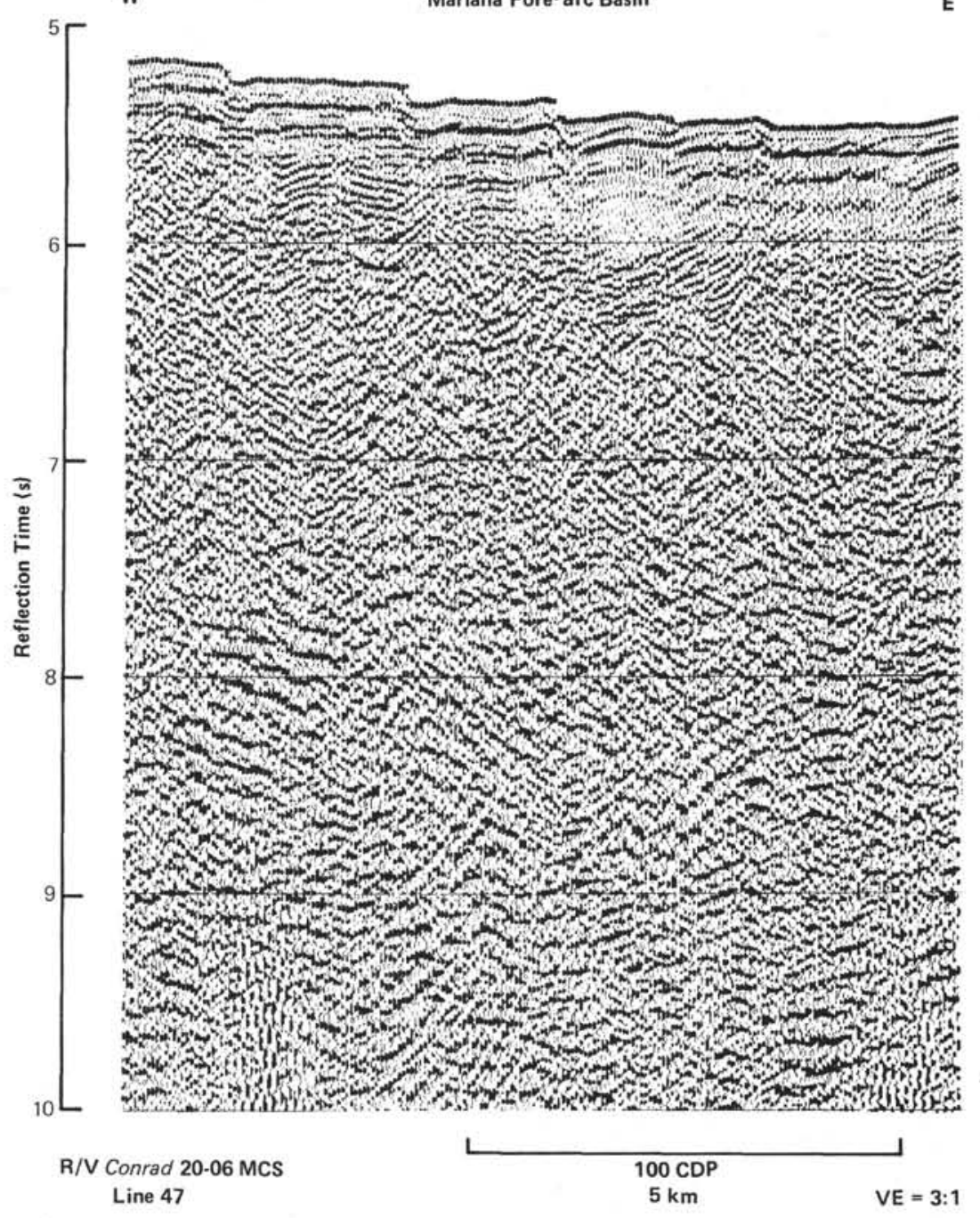

Figure 10. Migrated multichannel reflection seismic profile about $10 \mathrm{~km}$ west of Site 459 , showing the high-angle faulting, down-dropped toward the trench, that pervades this part of the Mariana fore-arc. (Profile taken from Conrad 20-06 MCS Line 47 [Mrozowski and Hayes, 1980].)

4) Site 459: to sample as close as possible to the trench-slope break in hopes of determining the origin and tectonic history of that feature; and

5) Sites 460 and 461 : to examine the inner trench wall for sediment accretion from the Pacific plate or for evidence of tectonic erosion.

\section{ACKNOWLEDGMENTS}

The authors are indebted to the scientific and ship's crew of the Kana Keoki for their enthusiastic support during data collection. We also thank Larry Wipperman and Steve Dang for their assistance in reducing and contouring much of the underway geophysical data described in this chapter. David Epp and John M. Sinton provided critical reviews of the manuscript.

This work was initially funded by the Nationl Science Foundation under the IPOD program of the Deep Sea Drilling Project; Columbia University 1976 and 1977 subcontracts CU-Hawaii-25903 (prime contract NSF-C482). Subsequent analysis was funded by IDOE/NSF contract OCE79-19636. This chapter is Hawaii Institute of Geophysics Contribution No. 1148.

\section{REFERENCES}

Hilde, T. W. C., Isezaki, N., and Wageman, J. M., 1976. Mesozoic seafloor spreading in the North Pacific. In Sutton, G. H., Man- ghnani, M. H., Moberly, R., and McAfee, E. U. (Eds,), The Geophysics of the Pacific Ocean Basin and Its Margin: American Geophysical Union Monograph 19: Washington (AGU), 205-226.

Jones, G. M., Hilde, T. W. C., Sharman, G. F., et al., 1978. Fault patterns in outer trench walls and their tectonic significance. J. Phys. Earth, 26 Supplement:S85-S101.

Karig, D. E., 1971. Structural history of the Mariana Island arc system. Geol. Soc. Am. Bull., 82:323-344.

, 1972. Remnant arcs. Geol. Soc. Am. Bull., 83:1057-1068.

Karig, D. E., and Sharman, G. F., 1975. Subduction and accretion in trenches. Geol. Soc. Am. Bull., 86:377-389.

Larson, R. L., and Hilde, T. W. C., 1975. A revised time scale of magnetic reversals for the Early Cretaceous and Late Jurassic. $J$. Geophys. Res., 80(No. 17):2586-2594.

LaTraille, S. L., and Hussong, D. M., 1980. Crustal structure across the Mariana Island arc. In Hayes, D. E. (Ed.), The Tectonic and Geologic Evolution of Southeast Asian Seas and Islands: American Geophysical Union Monograph 23: Washington (AGU), 209-221.

Mrozowski, C. L., and Hayes, D. C., 1980. A seismic reflection study of faulting in the Mariana fore-arc. In Hayes, D. E. (Ed.), The Tectonic and Geologic Evolution of Southeast Asian Seas and Islands: American Geophysical Union Monograph 23: Washington (AGU), 223-234.

Tracey, J. I., Jr., Schlanger, S. O., Stark, J. T., et al., 1964. Geology and hydrology of Guam, Mariana Islands. Prof. Pap. 403A: Washington (U.S. G. S.), A1-A104. 
Table 1. Seismic stations: Mariana arc, fore-arc, Trench, and Pacific plate (LaTraille and Hussong, 1980).

\begin{tabular}{|c|c|c|c|c|c|c|c|c|c|c|c|c|c|c|c|c|c|}
\hline \multirow[b]{2}{*}{ Station } & \multirow[b]{2}{*}{ Position } & \multirow{2}{*}{$\begin{array}{l}\text { Water } \\
\text { Depth at } \\
\text { Receiver } \\
(\mathrm{km})\end{array}$} & \multicolumn{7}{|c|}{ Velocity $(\mathrm{km} / \mathrm{s})$} & \multirow{2}{*}{$\begin{array}{l}\text { Datum } \\
\text { Water } \\
\text { Depth } \\
(\mathrm{km})^{\mathrm{a}}\end{array}$} & \multicolumn{6}{|c|}{ Thickness $(\mathrm{km})$} & \multirow{2}{*}{$\begin{array}{c}\text { Total Depth } \\
\text { to Mantle } \\
(\mathrm{km})\end{array}$} \\
\hline & & & 1 & 2 & 3 & 4 & 5 & 6 & 7 & & 1 & 2 & 3 & 4 & 5 & 6 & \\
\hline 13 & $\begin{array}{r}17^{\circ} 49.0^{\prime} \\
145^{\circ} 41.0^{\prime}\end{array}$ & 2.97 & $2.56^{\mathrm{b}}$ & 3.13 & 4.61 & 6.54 & & & & 2.60 & 1.36 & 0.96 & 1.15 & & & & \\
\hline 14 & $\begin{array}{r}17^{\circ} 49.3^{\prime} \\
145^{\circ} 54.2^{\prime}\end{array}$ & 2.72 & $2.00^{\mathrm{c}}$ & 3.31 & 4.61 & 5.94 & & & & 2.68 & 1.03 & 1.37 & 1.48 & & & & \\
\hline 15 & $\begin{array}{r}17^{\circ} 49.9^{\prime} \\
146^{\circ} 03.3^{\prime}\end{array}$ & 2.69 & $2.00^{c}$ & 3.63 & 4.73 & 6.32 & 7.22 & & & 2.85 & 0.80 & 1.58 & 1.15 & 1.77 & & & \\
\hline 16 & $\begin{array}{r}17^{\circ} 50.3^{\prime} \\
146^{\circ} 12.8^{\prime}\end{array}$ & 2.78 & $2.00^{\mathrm{C}}$ & 3.83 & 4.61 & 6.55 & & & & 3.07 & 0.49 & 1.35 & 2.04 & & & & \\
\hline 17 & $\begin{array}{r}17^{\circ} 50.4^{\prime} \\
146^{\circ} 26.7^{\prime}\end{array}$ & 3.32 & $2.00^{\mathrm{c}}$ & 3.94 & 5.80 & 6.39 & & & & 3.37 & 1.00 & 2.22 & 1.13 & & & & \\
\hline 18 & $\begin{array}{r}17^{\circ} 50.6^{\prime} \\
146^{\circ} 44.6^{\prime}\end{array}$ & 3.43 & $2.00^{c}$ & 4.29 & 6.15 & & & & & 3.52 & 0.40 & 2.93 & & & & & \\
\hline 19 & $\begin{array}{r}17^{\circ} 50.8^{\prime} \\
146^{\circ} 55.6^{\prime}\end{array}$ & 3.45 & $2.00^{\mathrm{c}}$ & 4.00 & 4.68 & 6.10 & & & & 3.71 & 0.29 & 1.44 & 1.99 & & & & \\
\hline 20 & $\begin{array}{r}17^{\circ} 51.4^{\prime} \\
147^{\circ} 10.7^{\prime}\end{array}$ & 3.88 & $2.00^{\mathrm{c}}$ & 4.14 & 5.32 & 6.50 & & & & 4.00 & 0.60 & 1.53 & 1.79 & & & & \\
\hline 23 & $\begin{array}{r}17^{\circ} 53.2^{\prime} \\
148^{\circ} 16.1^{\prime}\end{array}$ & 6.49 & $2.00^{\mathrm{c}}$ & 4.11 & 5.39 & 6.92 & 8.20 & & & 6.25 & 0.25 & 1.65 & 1.53 & 1.28 & & & 10.96 \\
\hline 24 & $\begin{array}{r}17^{\circ} 52.9^{\prime} \\
148^{\circ} 31.7^{\prime}\end{array}$ & 6.01 & $2.00^{\mathrm{C}}$ & $3.50^{\mathrm{a}}$ & 5.39 & 6.60 & 7.91 & & & 5.89 & 0.30 & 1.09 & 0.90 & 2.04 & & & 10.22 \\
\hline 25 & $\begin{array}{r}17^{\circ} 52.4^{\prime} \\
148^{\circ} 48.0^{\prime}\end{array}$ & 5.77 & $2.00^{c}$ & $3.06^{\mathrm{b}}$ & 4.11 & 5.89 & 6.54 & 7.38 & 8.20 & 5.61 & 0.15 & 0.49 & 1.13 & 0.92 & 1.20 & 2.90 & 12.40 \\
\hline 26 & $\begin{array}{r}17^{\circ} 52.5^{\prime} \\
149^{\circ} 04.9^{\prime}\end{array}$ & 5.56 & $2.00^{\mathrm{C}}$ & $4.00^{\mathrm{a}}$ & 5.88 & 6.85 & 8.03 & & & 5.40 & 0.19 & 2.17 & 0.91 & 1.83 & & & 10.50 \\
\hline 27 & $\begin{array}{r}17^{\circ} 52.7^{\prime} \\
149^{\circ} 24.1^{\prime}\end{array}$ & 5.22 & $3.12^{b}$ & 4.25 & 5.40 & 6.53 & & & & 5.00 & 0.78 & 0.55 & 1.63 & & & & \\
\hline 28 & $\begin{array}{r}17^{\circ} 52.7^{\prime} \\
149^{\circ} 37.3^{\prime}\end{array}$ & 4.85 & - & 3.26 & 5.30 & 7.18 & & & & 4.58 & - & 2.31 & 1.97 & & & & \\
\hline 29 & $\begin{array}{r}17^{\circ} 53.9^{\prime} \\
149^{\circ} 53.2^{\prime}\end{array}$ & 4.98 & $2.00^{\mathrm{a}}$ & 4.29 & 5.86 & 7.86 & & & & 5.08 & 0.15 & 2.40 & 2.20 & & & & \\
\hline
\end{tabular}

a Averaged along the datum for each station.

b Average velocity - a gradient, not a discrete layer,

c Assumed velocity.

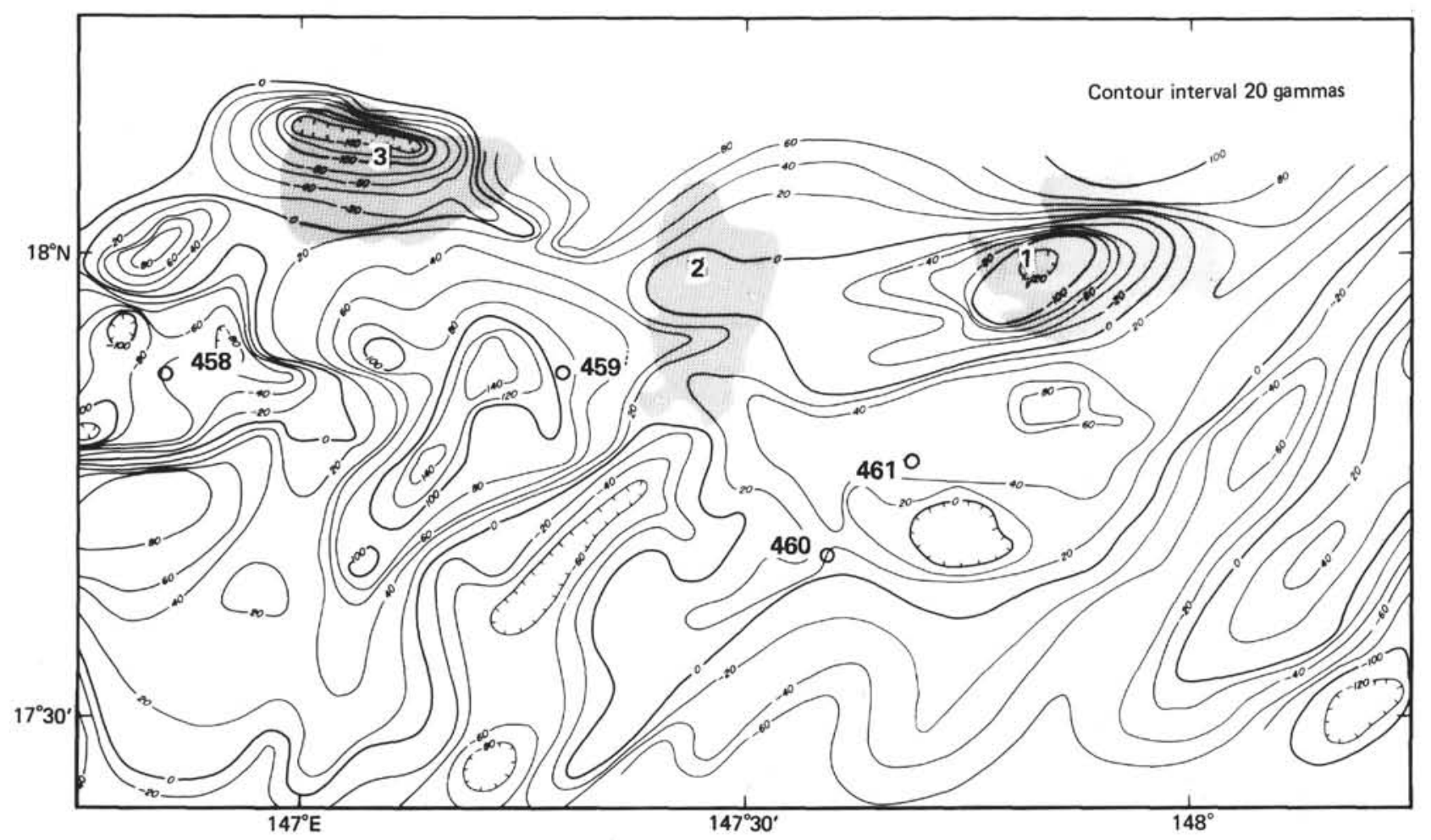

Figure 11. Total field magnetic intensity anomaly map, showing relative position of seamounts (shaded regions 1, 2, and 3) and DSDP Leg 60 drill sites (open circles). Map is portion of Plate 1 (back pocket). 
STRUCTURE AND TECTONICS

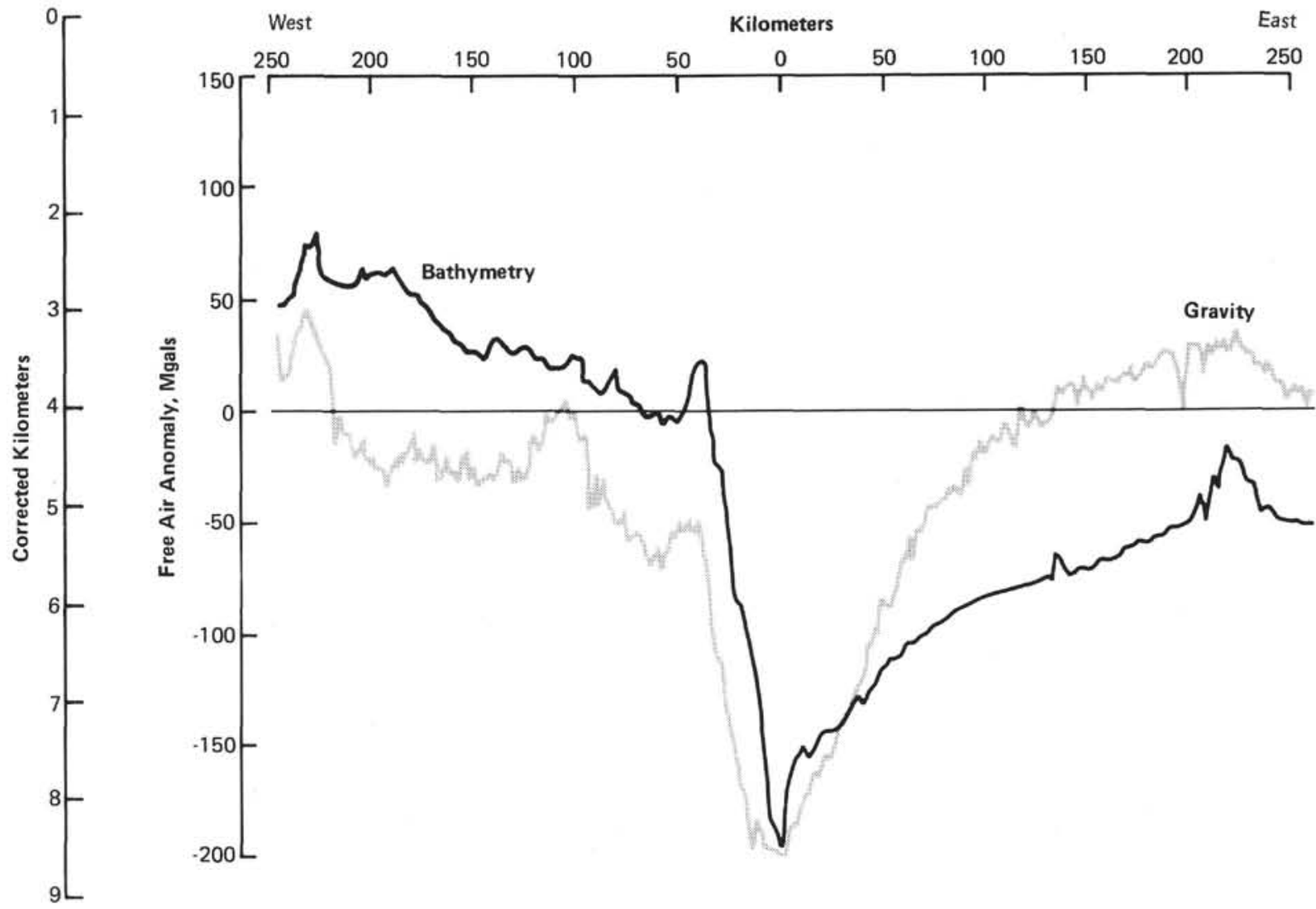

Figure 12. Bathymetry and gravity profiles across the study area. The free-air gravity anomaly generally follows the trend of the bathymetry except for the anomalous region on the fore-arc $100 \mathrm{~km}$ west of the trench axis.

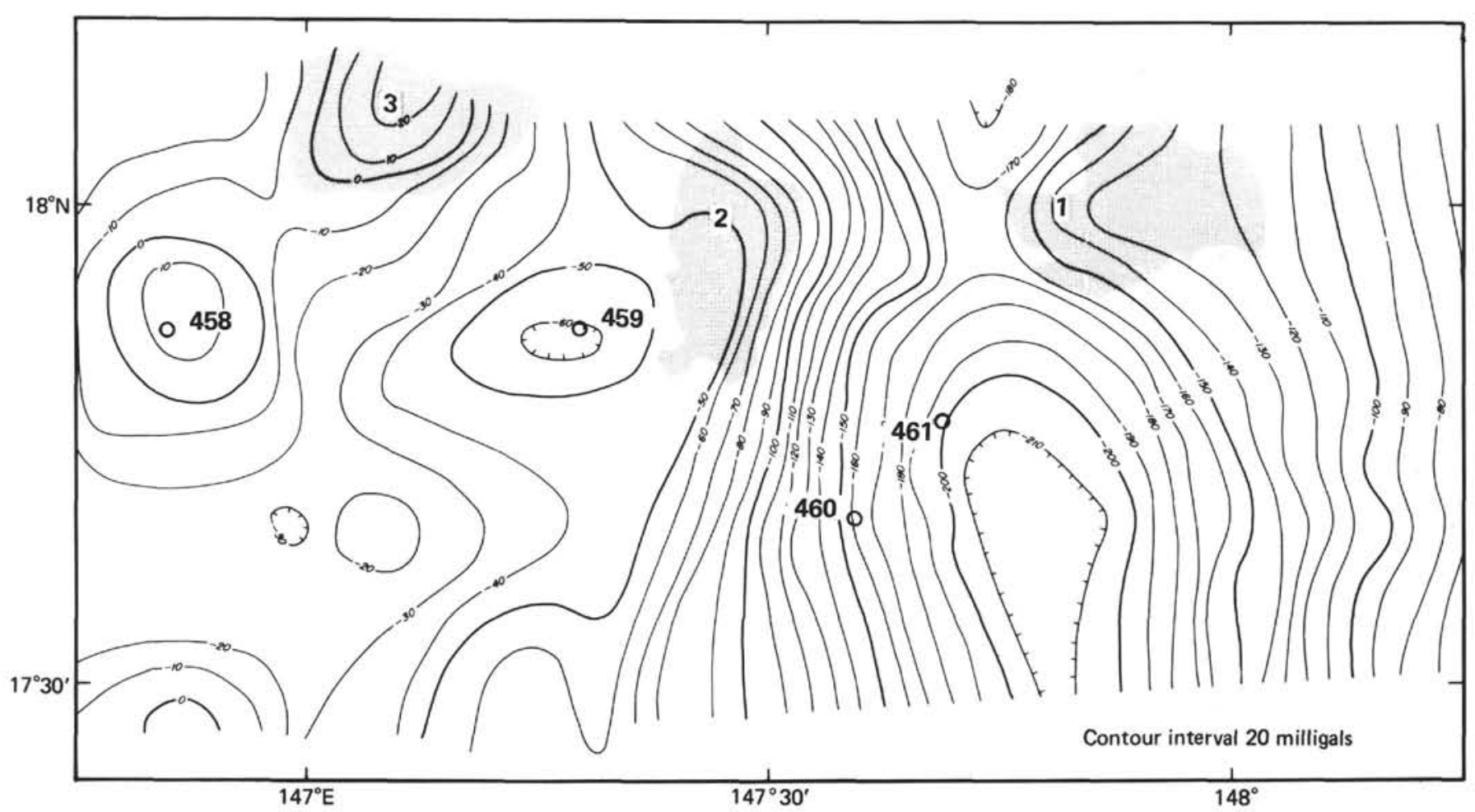

Figure 13. Free-air gravity anomaly map, showing relative position of seamounts (shaded regions 1, 2, and 3) and DSDP Leg 60 drill sites (open circles). Map is a portion of Plate 1 (back pocket). 
Table 2. Piston core drilling.

\begin{tabular}{|c|c|c|c|c|c|c|c|}
\hline $\begin{array}{l}\text { Core } \\
\text { No. }\end{array}$ & Type & Latitude $\mathrm{N}$ & Longitude E & $\begin{array}{l}\text { Length } \\
\text { Recovered } \\
\text { (cm) }\end{array}$ & $\begin{array}{l}\text { Water } \\
\text { Depth } \\
(\mathrm{m})\end{array}$ & Sediment Description & General Location \\
\hline 10 & PC & $17^{\circ} 40^{\prime}$ & $147^{\circ} 17^{\prime}$ & 464 & 4012 & $\begin{array}{l}\text { clayey silt-primarily } \\
\text { volcanic ash, some } \\
\text { radiolarians and } \\
\text { layers of pumice } \\
\text { fragments pebble- } \\
\text { sized }\end{array}$ & $\begin{array}{l}\text { in arc-trench gap near } \\
\text { Target SP 3c }\end{array}$ \\
\hline 11 & PC & $17^{\circ} 40^{\prime}$ & $147^{\circ} 17^{\prime}$ & 689 & 3985 & $\begin{array}{l}\text { clayey silt-primarily } \\
\text { volcanic ash, some } \\
\text { radiolarians }\end{array}$ & same as 10 \\
\hline 12 & PC & $17^{\circ} 46^{\prime}$ & $147^{\circ} 40^{\prime}$ & 490 & 6915 & $\begin{array}{l}\text { clayey silt-primarily } \\
\text { volcanic ash with } \\
\text { some foraminifers } \\
\text { (Pleistocene to } \\
\text { Holocene age) }\end{array}$ & $\begin{array}{l}\text { on inner wall of trench } \\
\text { near SP } 2\end{array}$ \\
\hline 13 & PCOD & $17^{\circ} 46^{\prime}$ & $148^{\circ} 32^{\prime}$ & 1165 & 6012 & pelagic clay & $\begin{array}{l}\text { old ocean crust in the } \\
\text { general vicinity }\end{array}$ \\
\hline 14 & PCOD & $17^{\circ} 47^{\prime}$ & $148^{\circ} 33^{\prime}$ & 1427 & 6008 & pelagic clay & of SP 1 \\
\hline 15 & PC & $17^{\circ} 49^{\prime}$ & $147^{\circ} 45^{\prime}$ & 177 & 7775 & $\begin{array}{l}\text { melange of detrital } \\
\text { and pelagic } \\
\text { material; mottled } \\
\text { clay both brown } \\
\text { and blue gray, } \\
\text { fragments of } \\
\text { serpentinite and } \\
\text { partially dissolved } \\
\text { calcareous material }\end{array}$ & $\begin{array}{l}\text { same as } 13 \\
\text { axis of the Mariana } \\
\text { Trench }\end{array}$ \\
\hline
\end{tabular}

Note: $\mathrm{PC}=$ piston core, $\mathrm{PCOD}=$ piston core with orienting device.

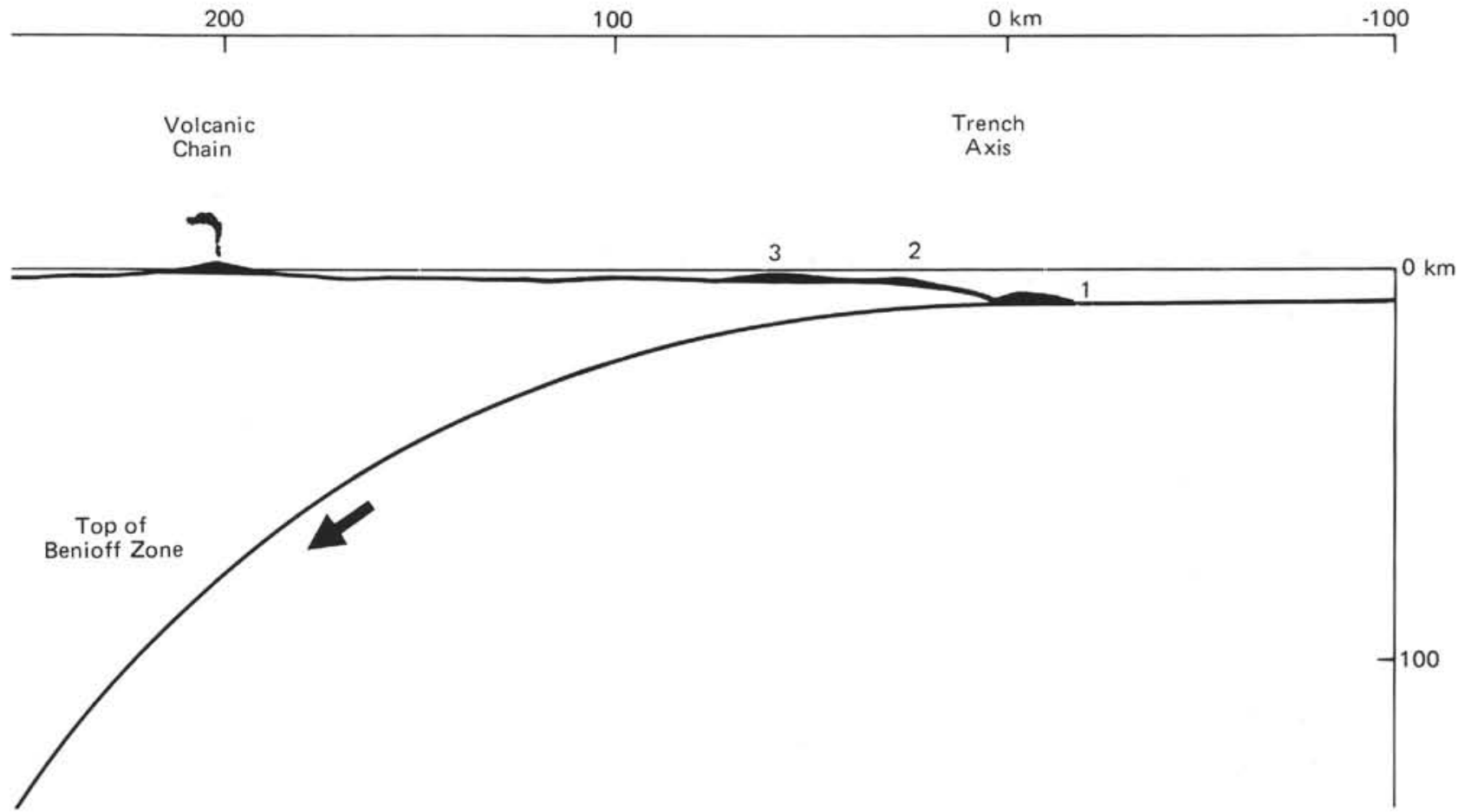

Figure 14. Simplified sketch of the Mariana arc subduction zone, with no vertical exaggeration, showing position of Seamounts 2 and 3 on the outer fore-arc and Seamount No. 1 in the trench axis. 